\title{
Benefits and Tensions of Shadow Education: Comparative Perspectives on the Roles AND Impact of Private Supplementary Tutoring IN THE Lives of HoNg Kong StUdents
}

\author{
Mark Bray \\ Comparative Education Research Centre \\ University of Hong Kong
}

\begin{abstract}
Over half of Hong Kong's secondary students receive private supplementary tutoring, and in the last grade of secondary schooling the proportion exceeds $70 \%$. Such tutoring is widely called shadow education because it mimics the regular system - as the curriculum in the schools changes, so it changes in the shadow; and as the regular school system expands, so does the shadow. The scale of private tutoring has grown significantly in the last two decades, and has become a standard feature of the lives of many families. Some tutoring is provided one-to-one by professionals, semi-professionals or amateurs; other tutoring is provided in small groups; and yet other tutoring is provided in lecture formats. Such tutoring demands significant financial investment by households, and also consumes substantial amounts of students' time. Some tutoring has benefits in helping slow learners to keep up with their peers and in stretching further the learning of high achievers. Parents may also prefer to pay other people to manage homework and related stresses. However, tutoring can also increase pressures on young people, and is not always effective. This paper presents Hong Kong data within a framework that compares local patterns with those in other parts of the world. It raises questions about the implications of patterns and about appropriate responses for families, educators and policy makers.
\end{abstract}

\section{Introduction}

Among major preoccupations for all youth and their families are the structures and processes of schooling. Hong Kong, like most economically-advanced societies, has an extended period of compulsory education and high enrolment rates in the post-compulsory period. Education is compulsory up to the end of Secondary Form 3 (Grade 9), which for most students means the age of 15; and reforms launched in 2009 expanded provision so that the vast majority would proceed to Secondary Form 6 (Grade 12) with fee-free education (Hong Kong, Information Services Department, 201, p.144). All youth and families are strongly aware that performance in the education system shapes future life opportunities. Young people who perform well are likely to have access to desirable university courses and to subsequent well-remunerated employment, while their counterparts who perform less well have more limited economic prospects. Awareness of this fact can create major stresses for youths and their families (Leung et al., 1986; Huan et al., 2008; Davies \& Guppy, 2010; Dunne et al., 2010).

Partly because of the stratified nature of the school system and post-school opportunities, alongside the regular school system has developed a shadow system of private supplementary tutoring. It is called a shadow system because it mimics the regular system. When new subjects and other curriculum changes are introduced in the regular system, before long they appear in the shadow; and as the regular system grows, so does the shadow. A major question is whether the shadow education reduces or increases stress for youths and their families.

\footnotetext{
a Correspondence can be directed to: mbray@hku.hk
} 
To address this question, the paper presents data from Hong Kong collected in 2011/12. The data indicate the scale and nature of shadow education, and perceptions by the recipients of the costs and benefits. To provide a wider lens through which to view the Hong Kong data, the paper commences by outlining features of shadow education around the world and particularly in Asia. The paper then turns to the Hong Kong data, explaining how the data were collected and what they say. The paper concludes by returning to the wider context.

\section{Shadow Education Around the World}

The history of private supplementary tutoring is probably as old as the history of formal schooling. The notion of seeking extra help for children and youths to help them to keep up with peers and/or to stretch their learning further is thus longstanding. However, in earlier decades and centuries supplementary tutoring was modest in scale, chiefly confined to relatively prosperous households. In the contemporary era, shadow education reaches a much wider spectrum of income groups and has become a major phenomenon around the world.

The literature on shadow education has particularly highlighted its significance in East Asia (e.g. Zeng, 1999; Dawson, 2010). South Korea has been well known for its hagwons, Japan for its counterpart juku, and Taiwan for its buxiban (see e.g. Seth, 2002; Roesgaard, 2006; Liu, 2012). These terms are sometimes translated as 'cram schools', though that description only addresses one dimension of the work of the institutions and tends to focus on the senior secondary level. These institutions in South Korea, Japan and Taiwan have been prominent for many decades. More recently, tutoring institutions have emerged in significant scale in Vietnam and Mainland China (see e.g. Dang, 2008; Xue \& Ding, 2009; Zhang, 2011). Some indicators of the scale of tutoring received both from institutions and less formal arrangements are evident from the following statistics:

- China: A 2010 survey of junior middle school students in Jinan city, Shandong Province, found that $28.8 \%$ were receiving tutoring in mathematics, $29.3 \%$ in English, and $11.6 \%$ in Chinese (Zhang, 2011, p.124).

- Japan: A 2007 national survey found that juku served $15.9 \%$ of Primary 1 children, that this proportion rose steadily in later grades, and that it reached $65.2 \%$ in Junior Secondary 3. In addition, $6.8 \%$ of Junior Secondary 3 pupils received tutoring at home, and $15.0 \%$ followed correspondence courses (Japan, 2008, p.13).

- $\quad$ South Korea: In $2008,87.9 \%$ of elementary school pupils were estimated to be receiving tutoring. In middle school the proportion was $72.5 \%$; and in general high school it was $60.5 \%$ (Kim, 2010, p.302).

- Taiwan: The 2001 Taiwan Education Panel Survey indicated that $72.9 \%$ of Grade 7 students were receiving tutoring for an average of 6.5 hours per week (Liu, 2012, p.49).

- Vietnam: Dang (2011) reviewed 2006 household survey data. He found that $32.0 \%$ of primary students were receiving tutoring. At lower and upper secondary levels, respective proportions were $46.0 \%$ and $63.0 \%$.

Shadow education is also extensive in much of South Asia (Pallegedara, 2011; Sujatha \& Rani, 2011; Bray \& Lykins, 2012), Southern Europe (Bray, 2011; Kassotakis \& Verdis, 2013), and parts of North Africa (Akkari, 2010; Sobhy, 2012). Percentages of students receiving shadow education are lower in Sub-Saharan Africa, North America, South America and Western Europe, but the phenomenon is growing in those regions (Bray, 2009, 2011; Burch, 2009; Lee et al., 2009). It is partly driven by the pressures of competition with the intensification of globalisation, and facilitated by the increasing acceptability of marketisation in the education sector. In some locations, including Mainland China but not Hong Kong, Japan or South Korea, teachers are permitted to gain extra incomes from providing private tutoring to the students for whom those teachers are already responsible in regular classes. 
One driver of demand for tutoring, particularly where enrolment rates are high, is the fear by students and families that they might lose out in competition if they do not invest in tutoring. This situation creates emotional stresses and financial burdens. Mauritius is among the countries in which successive governments have sought to address the problem. A 2001 policy document, evocatively entitled Ending the Rat Race in Primary Education, stated that private tutoring was "exerting immense psychological pressure on both students and their parents and perverting the very function of the school within society" (Mauritius, 2001, p.3). The government embarked on various measures to dampen demand, though with limited success (Bray, 2009, p.61-64). A 2006 review of the education system (Bah-lalya, 2006, p.75) stated that interviewees felt that their children would lose out on essential parts of the curriculum if they did not participate in private tutoring; and subsequent parliamentary debate observed that "children spend an average of 9 hours a day in regular and additional tutoring while adults have a 7-hour standard working day" (Mauritius, 2011a, p.3). At the time of the debate, the government already prohibited the provision (and receipt) of supplementary tutoring during the first three grades of primary school, and the authorities then extended this prohibition to the fourth grade (Mauritius, 2011b). However, the prohibition was not universally respected, and in any case it only applied to the first four grades. Although academic dimensions of schooling were dominant and pupils felt unable to engage in more balanced afterschool activities, families felt trapped by the system. Similar remarks have been made in many other contexts (see e.g. Dawson, 2010; Silova, 2010; Barrow \& Lochan, 2012; Bray et al., 2013).

However, such emphasis on possible negative sides of supplementary tutoring must be balanced by possible positive sides. Most obviously, effective tutoring can help slow learners to keep up with their peers, and in this way can support children's self-esteem and sense of achievement. In France, for example, Oller and Glasman (2013, p.7) have pointed out that tutoring support programmes:

act as 'intermediary spaces' in which children and adolescents have the chance to admit gaps in their knowledge without being punished at school or harassed by impatient parents. Students can thus do and redo tasks they did not perform well and, ultimately, take charge of their own learning.

Equally, tutoring can stretch the learning of high achievers, giving them satisfaction that they might not otherwise feel when moving at the pace of the majority in their classes. For the parents, investment in tutoring may give a feeling that they are doing what they can for their children at crucial stages in their children's lives; and effective tutoring arguably enhances overall levels of human capital for society.

\section{Shadow Education in Hong Kong}

\section{Data Collection and Description}

The data reported below were collected from students through both questionnaires and interviews. The survey was conducted in 16 secondary schools, representing 3.0 per cent of the total number in Hong Kong. Among these schools was a range of ability bands. The Hong Kong authorities group government and aided institutions into three bands according to the achievement scores of their student intakes during the last two years of primary schooling. Band One has the high achievers, Band Two has the middle achievers, and Band Three has the low achievers.

For the research, within each school two classes of each grade were randomly selected; and 1,646 student questionnaires were administered among which 1,624 usable responses (98.7\%) were received. Among them 59.5\% were from Form 3, and 40.5\% were from Form 6. In order to secure data about tutoring not only during term-time but also during vacations, students were asked about tutoring received within the previous 12 months (i.e. including a period of Form 2 for Form 3 students, and Form 5 for Form 6 students). Options on the types of tutoring included oneto-one, small group, lecture style, online, and others. Data were also collected on numerous other 
dimensions, estimated family incomes, the time spent on tutoring, and students' perceptions of the impact on their leisure activities.

In addition to the questionnaire component, 105 students were randomly selected for individual interview. In both Form 3 and Form 6, efforts were made to interview both students who received tutoring and who did not receive tutoring. The text that follows draws on both the quantitative findings and insights from the interview data.

\section{Scale, Intensity and Financial Burden}

Overall, 53.8 per cent of sampled Form 3 students and 71.8 per cent of Form 6 students reported that they had received private supplementary tutoring during the previous 12 months. These figures are comparable with those reported above from South Korea and Taiwan, and are considerably higher than in most other societies (Bray, 2009, 2011).

It is commonly assumed by laypeople that more tutoring is received by lower achievers (who are arguably more in need of it) than by high achievers. The data showed in fact that students in the higher-band schools were more likely to receive tutoring than their counterparts in lower-band schools. Thus, $74.2 \%$ of students in the sampled Band One schools received tutoring, compared with $61.7 \%$ of students in Band Two schools and $48.6 \%$ of students in Band Three schools.

However, students compare themselves not with the total population of students in Hong Kong but with their peers in the same schools. The questionnaire asked respondents to assess their performance relative to peers in the same grades in their schools. The students who rated themselves as good were more likely to receive tutoring than those who rated themselves as excellent, perhaps because the good students wished to reach the top ranks and those who considered themselves to be excellent were already confident of their performance. The students who described themselves as fair were the least likely to receive tutoring, while those who described their performance as poor or very poor were the most likely to receive tutoring.

Table 1 shows the intensity of tutoring. English, mathematics and Chinese were the most popular subjects, in which many students received one to two hours of tutoring per week during the ordinary and holiday seasons, and more during the examination season. Many students received tutoring in more than one subject. Form 3 students reported an average of 5.44 hours per week in tutoring during the examination season, while their counterparts on Form 6 reported an average of 4.76 hours (Table 2). Since in addition students needed time for travel, preparation and follow-up, this was a significant overall commitment.

Table 1: Time spent on private tutoring by Hong Kong secondary school students, by subject and season (hours per week)

\begin{tabular}{lc|ccc|ccc|ccc}
\hline & $\begin{array}{c}\text { \% of all } \\
\text { students\# }\end{array}$ & \multicolumn{3}{c|}{ Ordinary season } & \multicolumn{3}{c|}{ Examination season } & \multicolumn{3}{c}{ Holiday season } \\
\cline { 3 - 10 } & $71.7 \%$ & 654 & 2.19 & $0.25-50.00$ & 583 & 2.50 & $0.50-50.00$ & 509 & 2.00 & $0.50-14.00$ \\
\hline English & $58.0 \%$ & 530 & 2.19 & $0.50-25.00$ & 499 & 2.85 & $0.50-51.00$ & 398 & 2.09 & $0.50-42.00$ \\
Mathematics & $38.8 \%$ & 325 & 1.88 & $0.25-48.00$ & 318 & 2.33 & $0.50-50.00$ & 244 & 1.70 & $0.50-12.00$ \\
Chinese & $13.4 \%$ & 98 & 1.92 & $0.25-18.00$ & 110 & 2.44 & $0.50-24.00$ & 75 & 1.95 & $0.50-1.95$ \\
Liberal Studies & $29.9 \%$ & 262 & 2.23 & $.025-24.00$ & 257 & 2.55 & $0.50-34.00$ & 205 & 2.37 & $0.30-42.00$ \\
Science* & $11.1 \%$ & 92 & 2.02 & $0.50-14.00$ & 92 & 2.57 & $0.50-25.00$ & 71 & 2.25 & $0.30-15.00$ \\
Business** & $8.8 \%$ & 63 & 1.83 & $0.50-7.50$ & 77 & 2.54 & $0.50-20.00$ & 40 & 1.91 & $0.50-8.00$ \\
Humanities*** & $3.4 \%$ & 28 & 2.27 & $1.00-10.00$ & 31 & 3.35 & $1.00-20.00$ & 25 & 2.28 & $1.00-8.00$ \\
\hline
\end{tabular}


MARK BRAY

Table 2: Time spent on private tutoring in all subjects, by grade and season (hours per week)

\begin{tabular}{llll}
\hline & Mean & S.D. & No. of cases \\
\hline Form 3 students & & & \\
During ordinary time & 3.92 & 6.10 & 517 \\
During examination time & 5.44 & 11.44 & 517 \\
During holiday time & 2.52 & 3.42 & 517 \\
Form 6 students & & & \\
During ordinary time & 4.70 & 6.44 & 471 \\
During examination time & 4.76 & 8.32 & 471 \\
During holiday time & 3.98 & 6.71 & 471 \\
\hline
\end{tabular}

Table 3 indicates the responses to the question whether the costs of tutoring were a burden to the students' families. One third (34.1\%) of respondents stated that these costs were a burden, and a further $17.3 \%$ strongly felt that they were a burden. Among households with estimated monthly incomes above HK\$15,000, the costs of tutoring per student were estimated to consume between $2.3 \%$ and $8.8 \%$ of the incomes. This burden might seem manageable, though the proportions would have to be multiplied for households with more than one child at school. The estimated burden of tutoring costs per child reached between $20.3 \%$ and $30.5 \%$ for households with estimated incomes between HK\$4,000 and HK\$5,999. The burden was greater still for households with incomes below that level - though the number of cases in the sample was small, presumably because most households in this group felt that they could not afford tutoring.

Table 3: Extent to which respondents felt that private tutoring was a financial burden

\begin{tabular}{l|cc|cc}
\hline \multirow{2}{*}{$\begin{array}{l}\text { What is your view on the statement that } \\
\text { "Private tutoring is a financial burden to } \\
\text { you and your family"? }\end{array}$} & \multicolumn{2}{|c|}{$\begin{array}{c}\text { Cost of Private Tutoring (HK\$/ } \\
\text { month) }\end{array}$} & \multicolumn{2}{c}{ No. of cases } \\
\cline { 2 - 5 } & Mean & SD & $\mathrm{N}$ \\
\hline strongly disagree & 1,287 & 1,293 & 84 & $8.8 \%$ \\
disagree & 1,239 & 1,031 & 256 & $26.7 \%$ \\
agree & 1,676 & 2,727 & 327 & $34.1 \%$ \\
strongly agree & 1,860 & 2,584 & 166 & $17.3 \%$ \\
no opinion & 1,782 & 3,834 & 127 & $13.2 \%$ \\
\hline Total & 1,571 & 2,469 & 960 & $100.0 \%$ \\
\hline
\end{tabular}

\section{Perceptions of Benefits}

On the other side of the equation were the perceived benefits. Students generally felt that tutoring improved their examination grades, confidence in examinations, revision skills, and learning strategies (Table 4). These are clearly important domains. The questionnaire also asked about the effects of tutoring on students' relationships with their school teachers. Respondents were more neutral in this domain, and the interviews suggested that it was not a major consideration for the students.

Examples of how the students perceived the benefits were provided by the interviews. One focus was on academic achievement. For instance:

Interviewer: Is [tutoring] effective?

Student: Yes.

Interviewer: How?

Student: I don't have to do homework at home.

Interviewer: Do you think it helps your homework?

Student: Yes. If there is something I do not know, I can ask the tutor. 
Table 4: Students' perceptions of effectiveness of private tutoring

\begin{tabular}{lcccccc}
\hline & \multicolumn{7}{c}{ Percentage \% } \\
\cline { 2 - 6 } Private tutoring has improved my ... & $\begin{array}{c}\text { Strongly } \\
\text { Disagree }\end{array}$ & $\begin{array}{c}\text { Disagree } \\
\text { Angly }\end{array}$ & $\begin{array}{c}\text { Agree } \\
\text { Agree }\end{array}$ & $\begin{array}{c}\text { No opinion } \\
\text { Mean* }\end{array}$ \\
\hline Examination grades & $(1)$ & $(2)$ & $(3)$ & $(4)$ & $(2.5)$ & 3.16 \\
Relationship with school teachers & 8.9 & 5.9 & 62.4 & 25.9 & 5.0 & 2.35 \\
Confidence in examinations & 1.9 & 38.3 & 21.9 & 4.5 & 26.6 & 3.09 \\
Revision skills & 1.2 & 10.5 & 55.4 & 25.8 & 6.6 & 3.07 \\
Confidence in school performance & 2.6 & 20.1 & 50.1 & 15.4 & 11.8 & 2.84 \\
Learning strategies & 1.4 & 11.9 & 53.0 & 24.8 & 8.9 & 3.06 \\
\hline
\end{tabular}

$\mathrm{N}=992$.

* In the questionnaire, 1 = strongly disagree, 2 = disagree, 3 = agree; 4 = strongly disagree; 2.5 = no opinion. Thus, "mean $>2.50$ " implies that students in general agreed with the statement, and "mean $<2.50$ " implies that students in general disagreed with the statement.

Interviewer: Do you think your performance improved after receiving tutoring?

Student: Yes.

(transcript code: S3-M-Yes)

Interviewer: Were your academic results better in the past?

Student: I got very low mark before. I usually got 20 to 30 marks in the past, but I improved after receiving tutoring and nearly passed. Sometimes I pass while sometimes I get a few marks less than the passing line.

(transcript code: S3-F-Yes)

Another student elaborated by contrasting school lessons with tutorial lessons:

Student: I think tutoring is very helpful. It definitely improves my subject....

Interviewer: Why do you think it's effective? In what way do you think it's effective?

Student: If I do not understand something in class, I can get through with [the tutor] and he can go more in depth with me.... He explains in a way that is easier for me to understand. Because I think I have a different learning style than most students. What the teacher does in school may not be suitable for me....

Interviewer: So you think the tutor makes the subject easier for you?

Student: Yes

Interviewer: How do you think he makes it easier for you? What is the difference between school teachers and tutor?

Student: The school teacher has to teach the whole group and in a way that everyone can learn; but for me sometimes it is not good because I might not understand, so the tutor just clarifies for me.

Interviewer: So the tutor offers quite a different way of teaching to you?

Student: Yes

(transcript code: S6-M-Yes)

A related question concerns relationships with peers. Some interviewees, especially ones in Form 6 , indicated that their decisions to seek tutoring were influenced by recommendations from friends and classmates. However, few said that receipt or non-receipt of tutoring significantly affected their friendship patterns and peer relationships. 


\section{Opportunity Costs}

Alongside the questions about the scale of tutoring were questions about what the students had to sacrifice when they received extra lessons. Focusing on after-school activities, Table 5 compares the responses of students who did and did not receive tutoring. Those without tutoring indicated that they had more time for sports, shopping, computer games and friends, though the differences between the two groups were not major. Interestingly, students with private tutoring spent more time playing musical instruments, perhaps indicating that their families considered both academic work and music to be important. The two groups had similar amounts of time to read for enjoyment.

Table 5: Differences in frequency of after-school activities between students with and without tutoring

\begin{tabular}{|c|c|c|c|c|c|c|c|}
\hline \multirow[b]{2}{*}{ Activities after school } & & \multicolumn{4}{|c|}{ Frequency (\%) } & \multirow[b]{2}{*}{$\begin{array}{l}\text { No. of } \\
\text { cases }\end{array}$} & \multirow[b]{2}{*}{$\begin{array}{c}\mathrm{F} \\
\left(\chi^{2} \text { test }\right)\end{array}$} \\
\hline & & $\begin{array}{c}\text { Never or } \\
\text { hardly } \\
\text { ever }\end{array}$ & $\begin{array}{l}\text { Once or } \\
\text { twice a } \\
\text { month }\end{array}$ & $\begin{array}{c}\text { Once or } \\
\text { twice a } \\
\text { week }\end{array}$ & $\begin{array}{l}\text { Every day } \\
\text { or almost } \\
\text { every day }\end{array}$ & & \\
\hline \multirow{2}{*}{$\begin{array}{l}\text { Reading for } \\
\text { enjoyment }\end{array}$} & With tutoring & $15.7 \%$ & $40.0 \%$ & $26.7 \%$ & $17.6 \%$ & 978 & \multirow{2}{*}{1.920} \\
\hline & Without tutoring & $18.4 \%$ & $38.4 \%$ & $26.0 \%$ & $17.3 \%$ & 620 & \\
\hline \multirow[t]{2}{*}{ Playing sports } & With tutoring & $15.8 \%$ & $32.0 \%$ & $40.4 \%$ & $11.8 \%$ & 985 & \multirow{2}{*}{$7.842^{* *}$} \\
\hline & Without tutoring & $15.8 \%$ & $26.4 \%$ & $42.6 \%$ & $15.2 \%$ & 625 & \\
\hline \multirow{2}{*}{$\begin{array}{l}\text { Playing musical } \\
\text { instrument }\end{array}$} & With tutoring & $46.6 \%$ & $18.6 \%$ & $24.2 \%$ & $10.6 \%$ & 976 & \multirow{2}{*}{$31.490 * * *$} \\
\hline & Without tutoring & $60.0 \%$ & $16.0 \%$ & $14.7 \%$ & $9.2 \%$ & 617 & \\
\hline \multirow[t]{2}{*}{ (Window) shopping } & With tutoring & $13.8 \%$ & $45.7 \%$ & $36.0 \%$ & $4.5 \%$ & 976 & \multirow{2}{*}{$6.584^{*}$} \\
\hline & Without tutoring & $14.4 \%$ & $42.9 \%$ & $35.3 \%$ & $7.4 \%$ & 617 & \\
\hline \multirow{2}{*}{$\begin{array}{l}\text { Playing computer } \\
\text { games }\end{array}$} & With tutoring & $14.1 \%$ & $18.7 \%$ & $32.0 \%$ & $35.1 \%$ & 983 & \multirow{2}{*}{$38.374 * * *$} \\
\hline & Without tutoring & $9.5 \%$ & $12.3 \%$ & $28.4 \%$ & $49.8 \%$ & 624 & \\
\hline \multirow{2}{*}{$\begin{array}{l}\text { Spending time with } \\
\text { friends }\end{array}$} & With tutoring & $4.3 \%$ & $23.6 \%$ & $29.0 \%$ & $43.1 \%$ & 985 & \multirow{2}{*}{$18.290 * * *$} \\
\hline & Without tutoring & $5.4 \%$ & $15.7 \%$ & $27.7 \%$ & $51.2 \%$ & 625 & \\
\hline
\end{tabular}

$*: p<0.10 ; * *: p<0.05 ; * * *: p<0.01$.

Table 6 is related to Table 5 with a focus on family activities. Compared to those without tutoring, students with tutoring spent more time with their families (parents or/and grandparents) in discussing school life, eating dinner together, discussing social issues or news, and watching television together. Again, however, this may reflect family background more than the opportunity costs of tutoring: parents who pushed their children to tutoring may have been more likely also to stress the importance of family activities.

Table 6: Differences in frequency of family activities between students with and without tutoring

\begin{tabular}{|c|c|c|c|c|c|c|c|}
\hline \multirow{2}{*}{\multicolumn{2}{|c|}{$\begin{array}{l}\text { Student's family activities (with parents } \\
\text { and grandparents) }\end{array}$}} & \multicolumn{4}{|c|}{ Frequency (\%) } & \multirow[b]{2}{*}{$\begin{array}{l}\text { No. of } \\
\text { cases }\end{array}$} & \multirow[b]{2}{*}{$\begin{array}{c}\mathrm{F} \\
\left(\chi^{2} \text { test }\right)\end{array}$} \\
\hline & & $\begin{array}{l}\text { Never or } \\
\text { hardly } \\
\text { ever }\end{array}$ & $\begin{array}{l}\text { Once or } \\
\text { twice a } \\
\text { month }\end{array}$ & $\begin{array}{l}\text { Once or } \\
\text { twice a } \\
\text { week }\end{array}$ & $\begin{array}{l}\text { Everyday } \\
\text { or almost } \\
\text { everyday }\end{array}$ & & \\
\hline \multirow[t]{2}{*}{ Discuss school life } & With tutoring & $19.4 \%$ & $26.1 \%$ & $31.0 \%$ & $23.5 \%$ & 988 & \multirow{2}{*}{$21.918^{* * *}$} \\
\hline & Without tutoring & $28.0 \%$ & $27.7 \%$ & $27.2 \%$ & $17.1 \%$ & 625 & \\
\hline \multirow[t]{2}{*}{ Help with homework } & With tutoring & $63.6 \%$ & $19.9 \%$ & $12.7 \%$ & $3.9 \%$ & 987 & \multirow{2}{*}{3.258} \\
\hline & Without tutoring & $67.7 \%$ & $16.9 \%$ & $12.2 \%$ & $3.2 \%$ & 622 & \\
\hline \multirow[t]{2}{*}{ Eat dinner together } & With tutoring & $2.5 \%$ & $4.5 \%$ & $11.6 \%$ & $81.5 \%$ & 987 & \multirow{2}{*}{$7.422 *$} \\
\hline & Without tutoring & $4.8 \%$ & $5.6 \%$ & $11.3 \%$ & $78.3 \%$ & 622 & \\
\hline \multirow{2}{*}{$\begin{array}{l}\text { Discuss social issues } \\
\text { or news }\end{array}$} & With tutoring & $14.2 \%$ & $23.4 \%$ & $39.6 \%$ & $22.8 \%$ & 987 & \multirow{2}{*}{$29.643 * * *$} \\
\hline & Without tutoring & $23.7 \%$ & $25.6 \%$ & $31.3 \%$ & $19.4 \%$ & 624 & \\
\hline \multirow[t]{2}{*}{ Watch TV together } & With tutoring & $8.5 \%$ & $8.9 \%$ & $25.2 \%$ & $57.3 \%$ & 987 & \multirow{2}{*}{5.570} \\
\hline & Without tutoring & $11.2 \%$ & $10.3 \%$ & $21.8 \%$ & $56.7 \%$ & 624 & \\
\hline
\end{tabular}

$*: p<0.10 ; * *: p<0.05 ; * * *: p<0.01$. 


\section{Sources of Pressure}

The following dialogue with a Form 6 student receiving tutoring reflected the pressure for grades, self-expectations and the roles of parents and teachers.

Interviewer: Do you feel pressure?

Student: Yes, a lot.

Interviewer: Where does it come from?

Student: Come from myself.

Interviewer: Do your parents give you pressure?

Student: My father looks at my results. I am much poorer than before. I am not performing well now. I have a high expectation on myself, but I have no time to reach a good level within a short period. I want to give up sometimes so became poorer recently. I can keep my level with my language subjects. My elective subjects give me a lot of pressure.

Interviewer: Do teachers give you pressure?

Student: Yes. Some of them do.

(transcript code: S6-F-Yes)

The question then is whether the tutoring reduces or increases the pressure. This particular student did not express a clear answer on this matter, but another student in a similar situation indicated that the tutoring increased the pressure.

Interviewer: Do school teachers give you pressure?

Student: Yes. Sometimes they encourage us to do better if they think we are capable. However, such an encouragement is also a pressure. Tutors give even greater pressure.

Interviewer: How do your tutors give you pressure?

Student: They may not put [direct] pressure. They may praise some outstanding students in front

of the whole class that make you embarrassed.

(transcript code: S6-F-Yes)

This student also received pressure from her parents. Her case resembled another who indicated that his parents would scold him if his results were poor, and would ask him to reduce his sports. However, these students did not necessarily resent the pressure since they felt that it could indeed push them to greater heights for their own benefit.

In contrast were students who felt that tutoring was ineffective. For example:

Interviewer: Do you feel it effective?

Student: No, I found it might not be effective for lower forms. That's why I stopped tutoring.

Interviewer: I see.

Student: Maybe the tutor did not teach well.... I had tried Putonghua [Chinese] tutoring. During the tutoring lesson, the tutor just read the story to us. I thought she wanted us to listen to more Putonghua.

(transcript code: S6-F-No)

Another student expressed the view that tutoring could overload students without benefit.

Student: When I was in secondary school, I could not follow up some subjects, mathematics. My parents advised me to have tutoring. But I thought that it was tiring to have tutoring after school and meanwhile the tutoring content was just repeated.

Interviewer: So you think that it is useless?

Student: I would not think that it is useless, but I think it may lead to an opposite result since tutoring to some extent is just endless drilling. My friends have tutoring and they have much homework to do. In some cases they even have to do the tutoring homework in school lessons.... I think that this is excessive and would lead to the opposite results since they were not able to 
catch what should be learned in school lessons. They do not pay attention in the lesson but keep doing the tutoring homework.

(transcript code: S3-F-No)

Much also depends on the approaches of the tutors. One student who felt that he was scolded frequently during school hours by the teachers was then scolded again after school hours by the tutor. Under such circumstances, it is perhaps unsurprising that this student was performing poorly and did not consider the tutoring to help.

Further diversity was revealed by other cases. Some students did not receive tutoring because they were confident and did not feel a need. Others felt that the absence of tutoring was itself a pressure: they would have liked to have tutoring, but their families could not afford it. Yet others felt that their lives were better without tutoring. One Form 6 student who used to receive tutoring reported that she felt more relaxed without it:

I know a classmate who has Economics tutoring. But her recent exam result is poorer than mine. I think no tutoring is better than with tutoring. Sometimes ... it would be very late if they attend tutoring after school. So everything shifted late, including bath, dinner and sleep. So people may feel tired the next day.

(transcript code: S6-F-No)

\section{Pedagogical Approaches}

Some of the comments above may be linked to pedagogical approaches. One-to-one tutoring is obviously different from lecture-style tutoring delivered by 'star' tutors, and may even be different from small group tutoring. At first sight, one-to-one tutoring might seem to be the most desirable since content and style of instruction can be tailored to the single students. Certainly the respondents themselves indicated that this was the preferred form of tutoring. However, some students highlighted the benefits of small group tutoring, chiefly that they could learn from classmates and perhaps had less pressure because the tutors focused on classmates as well as on them. This dimension was also evident in some responses concerning lecture-style tutoring: some students actively preferred the anonymity of the large classes.

\section{Implications}

The above remarks underline the complexity of processes and relationships. The learning approaches imposed by the education system and/or chosen by the students themselves are strongly influenced by structural traditions in schooling, the motivations and personalities of the students, their family circumstances, and their relationships with teachers and peers. Equally, in the domain of private tutoring much depends on the motivations, personalities, pedagogical skills and marketing approaches of the tutors.

The question then, for a conference devoted to youth counselling, concerns the implications for the youth and for the adults who support and interact with them. Certainly tutoring is not a universal remedy for reducing stress, since it can also increase it; but more positively the right types of tutoring can certainly help students to keep up with their peers and cope with the pressures of the education system.

At the same time, this paper may raise some fundamental questions about the education system within which the youth have to operate. The high-sounding goals of the Hong Kong government's education reform include construction of "a learning environment that will induce students to be curious, to question and to explore", and that "will give students the opportunity to exhibit their abilities in independent thinking and creativity, and thus nurture more creative talents" (Hong Kong, Education Commission, 2000, p.34). The ultimate objective, the document declared is "to enable every student to achieve all-round development according to his/her own attributes" (p.36). Yet 
not all students and families feel that the system achieves these attributes. Although the reform document stressed a "no loser" principle (p.36), many students and families fear becoming losers, partly because they know that the competitive reality has to produce losers as well as winners. They invest in private tutoring as a form of protection against losing.

Some of the underlying forces may be illustrated by experiences linked to Liberal Studies. This subject was introduced in the reform, and had its first public examinations in 2012. It permitted and required considerable flexibility, with an issue-enquiry approach that aimed to "develop independent learning capabilities and cross-curricular thinking" (Hong Kong, Curriculum Development Council, 2007, p.2). Yet Table 1 above shows that $13.4 \%$ of the sampled students in 2011/12 were receiving tutoring in Liberal Studies. The percentage was much lower than in English, Mathematics, Chinese and Science; but it is noteworthy, given the orientation and design of the subject, that it was on the list at all. Among Form 6 students sampled, 16.6\% were receiving tutoring in Liberal Studies - and much of this tutoring was of the large-lecture examination-oriented type that was the antithesis of the goals of the official curriculum (Chan, 2012). One major driving force was anxiety by parents and families who faced new structures and felt unwilling to take risks. Again the stresses caused by the curriculum reform were evident; and for at least some students the tutoring techniques and the demands of time and finance may have increased rather than reduced those stresses.

\section{Conclusions}

In some parts of the world, private supplementary tutoring has become so common that it is perceived as a natural element of the lives of students and their families. With reference to Egypt, for example, Hartmann (2013, p.59) observed that:

Rather than a remedial measure for weak students, private and group tutoring have become a 'normal' and seemingly indispensable part of the education process..., and prevail across social classes and educational stages.

Similar remarks have been made in Turkey (Gök, 2010), Sri Lanka (Suraweera, 2011) and Greece (Kassotakis \& Verdis, 2013). Hong Kong does not currently have shadow education enrolment rates at quite the levels of these countries, but it is not far behind. In particular, when $71.8 \%$ of Form 6 students receive forms of shadow education, the $28.2 \%$ who do not are the exception rather than the norm.

From a systemic perspective, the fact that so many Hong Kong students and their families seem to consider private supplementary tutoring to be a necessary investment sends a message about the mainstream school system as well as about the shadow. It also raises a warning signal about wider social implications. While many families can easily afford shadow education, for some it is a financial burden and for others it is out of reach. In these circumstances, shadow education is a stratifying force behind the façade that stresses equality of opportunity through fee-free education.

The scale, nature and intensity of the shadow sector send some warnings about psychological well-being. The demands of education systems create major pressures for young people and their families, particularly at the time of end-of-secondary watershed examinations but also in lower grades. Students in parts of East Asia may experience heavier academic burdens and greater stress than their counterparts in other cultures (Huan et al., 2009; Dunne et al., 2010; Ahn \& Baek, 2013). Certain types of tutoring can help certain types of student, though it is obvious that low-income households cannot afford the same sorts of support as can high-income households - and some students whose families do invest in tutoring might be better off without it. Alongside the anticipated outcomes, shadow education may have unintended consequences for youths and their families.

In Hong Kong, as elsewhere, it would be unwise to make blanket recommendations on what sorts and volumes of tutoring are appropriate and inappropriate for what types of youth. This is because individual circumstances must be taken into account, with attention not only to the available 
finances and opportunity costs for the students but also to the availability of tutors with personalities and pedagogical approaches that can match the learning styles of the learners. At the same time, the counselling profession might note the extent to which the scale of shadow education has grown.

Finally, just as the shadow on a sundial tells the observer about the changing time of day, the shadow of an education system can tell the observer about the changing pressures in society. The Hong Kong government's education reform documents barely recognised the existence of the shadow sector, and inadequate attention is given in the counterpart documents of other countries. Arguably shadow education should be a much more central component of professional discussion not only in Hong Kong but also internationally.

Acknowledgement: An earlier version of this paper was presented as a keynote address to the conference on 'Youth Counselling: Dialogue, Practice and Passion' organised by the Department of Social Work and Social Administration at the University of Hong Kong, 7-8 December 2012. Helpful comments were received from several people, and in particular Samson Tse and Paul Wong. The research was supported by the General Research Fund (GRF) of the Hong Kong Research Grants Council (RGC), Project 741111. The research team, led by Mark Bray, includes Ora Kwo, Chad Lykins, Emily Mang, Wang Dan and Zhan Shengli. Several PhD students have also assisted, in particular Nutsa Kobakhidze, Li Wenjian, Kevin Yung, and Zhang Wei. The author expresses appreciation to them all.

\section{References}

Ahn, S.Y. \& Baek, H.J. (2013). Academic Achievement-Oriented Society and its Relationship to the Psychological Well-being of Korean Adolescents'. In C.C.Yi (ed.). The Psychological Well-being of East Asian Youth. Dordrecht: Springer, pp.265-279.

Akkari, A. (2010). Privatizing Education in the Maghreb: A Path for a Two-Tier Education System. In A.E. Mazawi \& R.G. Sultana (eds.). Education in the Arab 'World': Political Projects, Struggles and Geometries of Power. New York: Routledge, pp.43-58.

Bah-lalya, I. (ed.) (2006). Mauritius: 2000-2005 Educational Reform. Paris: IIEP-UNESCO and Association for the Development of Education in Africa (ADEA) Working Group on Education Sector Analysis (WGESA).

Barrow, D.A. \& Lochan, S. (2012). Supplementary Tutoring in Trinidad and Tobago: Some Implications for Policy Making. International Review of Education, 58 (3), 405-422.

Bray, M. (2009). Confronting the Shadow Education System: What Government Policies for What Private Tutoring? Paris: UNESCO International Institute for Educational Planning (IIEP). http:// www.unesco.org/iiep/eng/publications/recent/abstracts/2009/Bray_Shadoweducation.htm [Accessed 19 February 2013].

Bray, M. (2011). The Challenge of Shadow Education: Private Tutoring and its Implications for Policy Makers in the European Union. Brussels: European Commission. http://www.nesse.fr/nesse/ activities/reports/the-challenge-of-shadow-education-1 [Accessed 19 February 2013].

Bray, M. \& Lykins, C. (2012). Shadow Education. Private supplementary tutoring and its implications for policy makers in Asia. Manila: Asian Development Bank. http://www.fe.hku.hk/cerc/ Publications/monograph_no_9.htm [Accessed 19 February 2013].

Bray, M., Mazawi, A. E. \& Sultana, R.G. (eds.) (2013). Private Tutoring across the Mediterranean: Power Dynamics and Implications for Learning and Equity. Rotterdam: Sense Publishers.

Burch, P. (2009). Hidden Markets: The New Education Privatization. New York: Routledge.

Chan, C. (2012). The Nature of Teaching and Learning in Hong Kong's Liberal Studies Curriculum: Students' Perceptions of Learning Experiences in Tutorial and Daytime Schools. MEd dissertation, The University of Hong Kong.

Dang, H.A. (2008). Private Tutoring in Vietnam: An Investigation of its Causes and Impacts with Policy Implications. Saarbrücken: VDM Verlag Dr. Muller.

Dang, H.A. (2011). Private Tutoring in Vietnam: A Review of Current Issues and its Major Correlates. Unpublished manuscript, Washington DC: The World Bank. 
Davies, S. \& Guppy, N. (2010). The Schooled Society: An Introduction to the Sociology of Education $\left(2^{\text {nd }}\right.$ ed.).Toronto: Oxford University Press.

Dawson, W. (2010). Private Tutoring and Mass Schooling in East Asia: Reflections of Inequality in Japan, South Korea, and Cambodia. Asia Pacific Education Review, 11 (1), 14-24.

Dunne, M. P., Sun, J., Nguyen, D.N.T., Thanh Truc, Kim, X.L. \& Dixon, J. (2010). The Influence of Educational Pressure on the Mental Health of Adolescents in East Asia: Methods and Tools for Research. Journal of Science [Hue University], 61,109-122.

Gök, F. (2010). Marketing Hope: Private Institutions Preparing Students for the University Entrance Examination in Turkey. In K. Amos (ed.). International Educational Governance. International Perspectives on Education and Society 12, London: Emerald, pp.123-134.

Hartmann, S. (2013). Education "Home Delivery" in Egypt: Private Tutoring and Social Stratification. In M. Bray, A.E. Mazawi \& R.G. Sultana (eds.). Private Tutoring across the Mediterranean: Power Dynamics and Implications for Learning and Equity. Rotterdam: Sense Publishers, pp.57-75.

Hong Kong, Curriculum Development Council (2007). Liberal Studies Curriculum and Assessment Guide (Secondary 4-6). Hong Kong: Curriculum Development Council and Hong Kong Examinations and Assessment Authority. http://www.edb.gov.hk/FileManager/EN/Content_5941/ls_e_070307. pdf [Accessed 19 February 2013].

Hong Kong, Education Commission (2000). Reform Proposal for the Education System in Hong Kong. Hong Kong: Education Commission. http://www.e-c.edu.hk/eng/reform/annex/Edu-reformeng.pdf [Accessed 19 February 2013].

Hong Kong, Information Services Department (2011): Hong Kong 2010. Hong Kong: Information Services Department. http://www.yearbook.gov.hk/2010/en/index.html [Accessed 19 February 2013].

Huan, V.S., Yeo, L. S., Ang, R.P. \& Chong, W.H. (2008). The Impact of Adolescent Concerns on their Academic Stress. Educational Review, 60(2), 169-178.

Japan, Ministry of Education and Training (2008). Report on the Situation of Academic Learning Activities of Children. Tokyo: Monbukagakusho Hokokusho. [In Japanese]

Kassotakis, M. \& Verdis, A. (2013). Shadow Education in Greece: Characteristics, Consequences and Eradication Efforts. In M. Bray, A.E. Mazawi \& R.G.Sultana (eds.), Private Tutoring across the Mediterranean: Power Dynamics and Implications for Learning and Equity. Rotterdam: Sense Publishers, pp.93-113.

Kim, K.K. (2010). Educational Equality. In C.J. Lee, S.Y. Kim \& D. Adams (eds.). Sixty Years of Korean Education. Seoul: Seoul National University Press, pp.285-325.

Lee, C.J., Park, H.J. \& Lee, H. (2009). Shadow Education Systems. In G. Sykes, B. Schneider \& D.N. Plank, (eds.). Handbook of Education Policy Research. New York: Routledge for the American Educational Research Association, pp.901-919.

Leung, P.W., Salili, F. \& Baber, F.M. (1986). Common Adolescent Problems in Hong Kong: Their Relationship with Self-esteem, Locus of Control, Intelligence and Family Environment. Psychologia, 29 (12), 91-101.

Liu, J. (2012). Does Cram Schooling Matter? Who Goes to Cram Schools? Evidence from Taiwan. International Journal of Educational Development, 32 (1), 46-52.

Mauritius, Ministry of Education and Scientific Research (2001). Ending the rat race in primary education and breaking the admission bottleneck at secondary level. Port Louis: Ministry of Education and Scientific Research. www.gov.mu/portal/goc/educationsite/file/reforms.pdf [Accessed 19 February 2013].

Mauritius, Government of (2011a). Debate No. 19 of 2011; Sitting of Tuesday 25 October 2011; Second Reading, The Education (Amendment) Bill. Port Louis: Parliament of the Republic of Mauritius.

Mauritius, Government of (2011b). The Education (Amendment) Bill (No. XXV of 2011). Port Louis, Government of Mauritius. 
Oller, A. \& Glasman, D. (2013). Education as a Market in France: Forms and Stakes of Private Tutoring. In M. Bray, A.E. Mazawi \& R.G. Sultana (eds.). Private Tutoring across the Mediterranean: Power Dynamics and Implications for Learning and Equity. Rotterdam: Sense Publishers, pp.77-91.

Pallegedara, A. (2011). Demand for Private Tuition Classes under the Free Education Policy: Evidence Based on Sri Lanka. Munich: Munich Personal RePEc Archive. (available at http://mpra.ub.unimuenchen.de/31969/1/MPRA_paper_31969.pdf).

Roesgaard, M. H. (2006). Japanese Education and the Cram School Business: Functions, Challenges and Perspectives of the Juku. Copenhagen: Nordic Institute of Asian Studies Press.

Seth, M. J. (2002). Education Fever: Society, Politics, and the Pursuit of Schooling in South Korea. Honolulu: University of Hawai'i Press.

Silova, I. (2010). Private Tutoring in Eastern Europe and Central Asia: Policy Choices and Implications. Compare: A Journal of Comparative and International Education, 40 (3), 327-344.

Sobhy, H. (2012). The De-facto Privatization of Secondary Education in Egypt: A Study of Private Tutoring in Technical and General Schools. Compare: A Journal of Comparative and International Education, 42 (1), 47-67.

Sujatha, K. \& Rani, P. G. (2011). Management of Secondary Education in India. New Delhi: Shipra and National University of Educational Planning and Administration (NUEPA).

Suraweera, A.V. (2011). Dr. Kannangara's Free Education Proposals in Relation to the Subsequent Expansion of the Tuition Industry. Dr. C.W.W. Kannangara Memorial Lecture 22, Mahargama, Sri Lanka: Department of Research and Development, National Institute of Education.

Xue, H. \& Ding, X. (2009). A Study on Additional Instruction for Students in Cities and Towns in China. Educational Research, 30 (1), 39-46. [In Chinese]

Zeng, K. (1999). Dragon Gate: Competitive Examinations and their Consequences. London: Cassell.

Zhang, Y. (2011). The Determinants of National College Entrance Exam Performance in China - With an Analysis of Private Tutoring. PhD dissertation, Columbia University. 